Maciej Jaszczyński (Paris)

\title{
INDO-EURopeAN RoOTS OF THE HELEN OF TroY
}

\section{Establishing Helen's divinity}

Firstly, it needs to be established that although Helen is widely known as - a mythological, yet mortal and definitely human figure in the Greek literature, she was in fact considered as a goddess in some parts of Greece. Already in 1893, the Swedish philologist Samuel Wide published a comprehensive review of the evidence for Helen's cult in Laconia in his monograph Lakonische Kulte ${ }^{1}$. She had a ísóv - a temple - in Sparta, but the main place of her cult was Therapne, where she was worshipped with Menelaus. From the oldest times, her cult in Laconia had a form of tree-worship - young girls would bring lotos flowers and olive oil and put them on plane trees ${ }^{2}$. We also know of the cult of $\mathrm{E} \lambda \dot{\varepsilon} v \eta \quad \delta \varepsilon v \delta \rho \tilde{i} \tau \iota \varsigma$ on Rhodes $^{3}$. Children were often put under the protection of Helen in her temple. According to Hesychius, there was a festival in Laconia called 'E $\lambda \dot{\varepsilon} v i \alpha$, where young women would carry baskets to the temple of Helen. Spartan Helen appears on many votive reliefs with Dioskouroi - her brothers Kastor and Polydeukes - which suggests that they were worshipped together ${ }^{4}$. One can also mention Helen's apotheosis together with Achilleus on the island of Leuce narrated by Philostrates in the Heroicus ${ }^{5}$. Thus it is proper to treat her at least as local Greek goddess and there is evidence that in fact she, or rather her 'prototype', was an important member of the Proto-Indo-European pantheon.

\footnotetext{
${ }^{1}$ S. WIDE, Lakonische Kulte, Leipzig 1893, p. 340-346.

${ }^{2}$ Ibidem, p. 340-341.

${ }^{3}$ Pausanias, Description of Greece, III, 19, 10, vol. II, Books 3-5 (Laconia, Messenia, Elis 1), trans. W.H.S. Jones, H.A. Ormerod, Cambridge Massachusett-London 1926 [= LCL, 188]: They say that this Polyxo desired to avenge the death of Tlepolemus on Helen, now that she had her in her power. So she sent against her when she was bathing handmaidens dressed up as Furies, who seized Helen and hanged her on a tree, and for this reason the Rhodians have a sanctuary of Helen of the Tree.

${ }^{4}$ S. Wide, Lakonische..., p. 344, after Hesychius.

${ }^{5}$ Philostrate, Sur les Héros, 54-55, ed. et trans. S. Follet, Paris 2017 [= CUF.SG, 531e].
} 


\section{Etymology of Helen's name}

As in the case of some Greek deities, we can firstly turn to the linguistic heritage and examine Helen's name and its etymology to establish whether we can trace it back to Proto-Indo-European times. As a curiosity, we can invoke the synchronic, folk etymology provided by Aeschylus in the Agamemnon who connected Helen with the aorist stem of the verb aip $\rho \dot{\varepsilon} \omega$ ' $\check{\lambda} \lambda$-' which can mean 'overpower, kill' to evoke her blame for the devastating effects of the Trojan War'

Many scholars have undertaken this task over the last century and no-one has been able to reach a fully satisfying conclusion. Some even deemed the challenge hopeless ${ }^{7}$. There have been three main lines of interpretation for her name, although there exist nine possible etymologies ${ }^{8}$.

The first one, proposed among others by Martin West derives Helen's name from the Proto-Indo-European root "swel- 'to shine', or as suggested by Stefan Höfler - ${ }^{*}$ swelh $_{1}$ ' to glow with heat ${ }^{\prime}$. It appears in many other Indo-European families ${ }^{10}$. This analysis is supported by Julius Pokorny who gives examples of other manifestations of this root, e.g. Vedic svárati 'shines', Greek itself has some

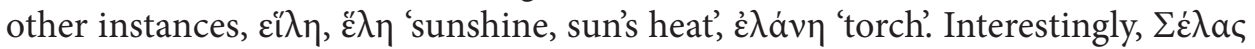
'light' and its derivatives, like $\sigma \dot{\varepsilon} \lambda \eta \nu \eta$ 'moon', are quite problematic and its relationship with the root is unclear. Semantically it fits, but the preservation of the initial /s/ before a vowel is not a typical outcome for Greek at any stage of its development ${ }^{11}$. Apart from that, we find Albanian diell 'sun', Old English swelan to 'burn', German schwelen, Lithuanian svilti 'grill', so the root itself is very well established.

There is a controversy between the roots ${ }^{*}$ swel- and ${ }^{*}$ swelh $_{1}-$. The LIV lists "swel- as the root meaning 'schwelen, Brennen' and "swelH- as the one with the significance of 'anschwellen' ${ }^{12}$. However, S. Höfler convincingly argues that in fact the correct root should be reconstructed as ${ }^{*}$ swelh $_{1}^{-}$. The evidence is the acute variant of the Lithuanian verb svilti, just mentioned, Old English swol - 'flame'

\footnotetext{
${ }^{6}$ Aeschylus, Agamemnon, 687-688, [in:] Aeschylus, vol. II, Agamemnon. Libation-Bearers. Eumenides.

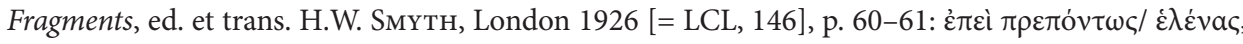

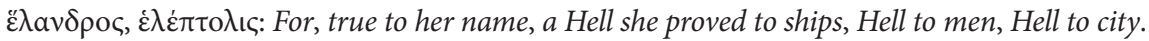

${ }^{7}$ P. Chantraine, Dictionnaire Étymologique de la Langue Grecque, Paris 1968, p. 335 (s.v. 'E $\lambda \dot{\varepsilon} v \eta:$ Quelle que soit l'interprétation tentée par les historiens de la religion, il est vain de chercher une étymologie).

${ }^{8} \mathrm{G}$. Sмоот, Helenos and the Polyphyletic Etymologies of Helen, https://classical-inquiries.chs.harvard. edu/helenos-and-the-polyphyletic-etymologies-of-helen/ [16 X 2017].

${ }^{9}$ S. HÖFler, "La Belle Hélène", a Generic Brothel, and the Development of ${ }^{*}$ CROHC Sequences in Ancient Greek, https://www.academia.edu/34917682/La_belle_Helene_Handout_SHORT [13 I 2018], p. 2.

${ }^{10}$ M. West, Indo-European Poetry and Myth, Oxford 2007, p. 231.

${ }^{11}$ A.L. Sihler, New Comparative Grammar of Greek and Latin, New York-Oxford 1995, p. 170 $171,216$.

${ }^{12}$ Lexikon der indogermanischen Verben, ed. H. Rix et al., Wiesbaden 2001, p. 609sq.
} 


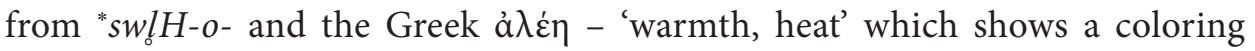
of the auslauting laryngeal ${ }^{13}$.

The key evidence in support of this line of derivation is the discovery of two archaic Laconian inscriptions, one from $675-650 \mathrm{BC}$, the other from the $6^{\text {th }}$ century $\mathrm{BC}$, where the name is spelled with the initial digamma ${ }^{14}$. This definitely rules out the direct derivation from $\sigma \varepsilon \dot{\lambda}$ as and the connection with the Vedic goddess Saranyu - the mare-mother of the Aśvins, proposed by some scholars, but allows to reconstruct an older form of the name as "Sweléna, with an expected development of *swe- into *he-, as in the Proto-Indo-European reflexive pronoun *swe (refl.) which surfaces in Attic Greek as $\varepsilon$. This suggests the derivation from the root ${ }^{*}$ swelh $_{1}$ - with the suffix ${ }^{*}$-nos $/{ }^{*} n e h_{2}>^{*} n \bar{a}$, very characteristic of the names of IndoEuropean gods, presumably meaning 'the lord of/lady of': Anatolian Tarhunnas, Indic Varuna, Greek Ov̉pavóc, Roman Neptūnus and Vulcānus, Lithuanian Perkúnas and others ${ }^{15}$. This would conveniently explain Helen's name as Lady of Light, as already proposed by J. Pokorny ${ }^{16}$.

There are, however, others who would like very much to connect Helen, her name and her story with the Vedic Saranyū. Otto Skutsch in his article on Helen points out that the spelling with the initial digamma is not fully authoritative, as we do find Helen's name spelled without a digamma on two Corinthian craters from the early $6^{\text {th }}$ century. The Doric dialect of Corinth retains the digamma wordinitially relatively long, the first known, and isolated, omission comes in early $5^{\text {th }}$ century in an inscription honoring those who died at Salamis. This version brings Helen perfectly in line with Saranyū, whose name is derived from the adjective sarana- - 'swift', phonetically matching with 'E $\lambda \dot{\varepsilon} v \eta$, if we assume that the Corinthian form is the original one ${ }^{17}$. This led O. Skutsch to believe that there were two separate Helens, one "Selena and the other "Swelena, who merged at some point in the Greek mythological and religious tradition. He justifies this radical idea, not only by two parallel possible etymologies, but also by the fact that Helen had two different identities in the Greek religious tradition. There was Helen, daughter of Zeus, sister of the Dioskouroi, taking over the solar attributes of the Dawngoddess, but we also have a lot of evidence that in historical times Helen was worshipped in multiples places in the Greek world as a vegetation deity, as mentioned

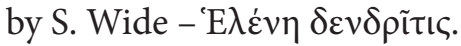

I consider the possibility of Helen being originally two separate entities to be highly unlikely. Especially because O. Skutsch creates this separate goddess

\footnotetext{
${ }^{13}$ S. HÖFLER, "La Belle Hélène"..., p. 2-3.

${ }^{14}$ Supplementum Epigraphicum Graecum, vol. XXVI, (1976-1977), ed. H.W. Pleket, R.S. Stroud, Alphen aan den Rijn-Germantown 1979, 457, 458, p. 123.

${ }^{15}$ M. West, Indo-European..., p. 137.

${ }^{16}$ J. Pokorny, Indogermanisches Etymologisches Wörterbuch, vol. I, Bern-München 1959, p. 1045 (s.v. swel-).

${ }^{17}$ O. Skutsch, Helen, Her Name and Nature, JHS 107, 1987, p. 190.
} 
*Selena, just to equate her with Saranyū, so to go back to her association with the Vedic Aśvins. This is quite an extreme concept, which needs a lot more evidence and justification to be convincing. No other Indo-European tradition provides any evidence for two separate goddesses, one *Selena and the other *Swelena. While the inconsistencies of the epigraphic evidence and very different roles of Helen in Greece are baffling, it is not enough to conjure an additional goddess for the Proto-Indo-European period merely to explain a specifically Greek problem.

The third concept, represented by Linda Clader completely discards Helen's associations with the root "swel- or with Saranyū and treats it as deriving from either of the homophones $\dot{\varepsilon} \lambda \dot{\varepsilon} v \eta$, one meaning 'basket of woven rope' and the other 'the torch of reeds', both of which she considers coming from the root *wel- 'to turn', not as J. Pokorny suggests "swel- in the case of the torch. She noticed that both objects can be produced by twisting reeds, which would explain their etymology. Her reconstructed version of Helen's name is thus ${ }^{*} W e l e n a$. She connects the name with the ritual practices found in Sparta where at the festival of Helenephoria baskets called $\dot{\varepsilon} \lambda \dot{\varepsilon} v a$ l were carried by young girls ${ }^{18}$.

I do not consider this to be a probable solution to the question of the etymology of Helen's name. While it is true that Helen was mostly worshipped in Laconia, she was still a very well-known figure in all of Greece, possibly quite archaic given her importance in the Homeric epics and parallels with other Indo-European traditions, so on this basis alone, it is difficult to imagine that her name derives from a local Laconian ritual practice.

Finally, it is also necessary to mention a new etymology proposed by GeorgesJean Pinault in his recent article. He completely refutes any connections with the Vedic Saranyu as linguistically impossible in the light of the epigraphic evidence of the spelling with a digamma and suggests that the Corinthian spelling might be a result of the Attic influence in the context of the vase-painting ${ }^{19}$. He also denies the legitimacy of M. West's reconstruction on the basis that the suffix -eno, which were to be added to the root "swel- is not productive in Greek. This, however, can be solved by positing the root "swelh ${ }_{1}^{-}$, as proposed and well argued by S. Höfler ${ }^{20}$. Instead, G.-J. Pinault tries to explain the name as a compound "suh $h_{1}-l-h_{1}$ eno > "suh $-l-h_{1}$ eno, which would mean 'having a year like a thread. Thus, he considers Helen's name to be related to the function of Greek Moĩpaı or Latin Parcae.

The circumstantial evidence, that is her association with the Divine Twins, similarities with the Vedic deities, explored in the following parts of this paper, strongly suggests that the character of Helen is old and Proto-Indo-European. As I have explained earlier, the existence of two Helens, one *Swelena from the root "swelh ${ }_{1}^{-}$'to shine', and the other *Selena, cognate with Vedic sarana - 'swift' and

${ }^{18}$ L. Clader, Helen. The Evolution from Divine to Heroic in Greek Epic Tradition, Leiden 1976 [= Mn.S, 42], p. 63sqq.

${ }^{19}$ G.-J. Pinault, Hélène retrouvée: l'étymologie de grec EA $\varepsilon \dot{v \eta}$, Бe 54, 2015, p. 157-162.

${ }^{20}$ S. Höfler, "La Belle Hélène”..., p. 2-3. 
thus Saranyū is completely improbable, as there is simply not enough evidence for that. When it comes to the epigraphic controversy of *Swelena versus *Selena, although the evidence is inconclusive, as a rule it is generally easier to explain, or overlook, the unexpected lack of digamma than its presence in the inscriptions, so I do think that $\mathrm{M}$. West and J. Pokorny are ultimately the closest ones to the truth by explaining her name as 'Lady of Light' or 'Lichtgöttin', although we have to keep in mind that the direct derivation from $\sigma \varepsilon \dot{z} \lambda \alpha \varsigma$ is not possible. G.-J. Pinault's idea is definitely viable linguistically, but the solar explanations fit much better culturally and comparatively.

\section{Proto-Indo-European Dawn and the Daughter of the Sun}

There have been numerous publications discussing the members of the divine family of Indo-European gods, e.g. Indo-European Poetry and Myth by M. West, or an article by Peter Jackson Light from Distant Asterisks ${ }^{21}$. Among the reconstructed deities we often find two similar figures: Dawn and the 'Daughter of the Sun'. The two are best preserved in the Vedic tradition as Ușās - Dawn and Sūryấ, which is the feminine form of Surya- - the Sun - with the shift of the accent, who is the wife of the Aśvins - the Divine Twins. The goddess of dawn is a very well attested Indo-European divinity and there is not doubt about her archaic character, even purely

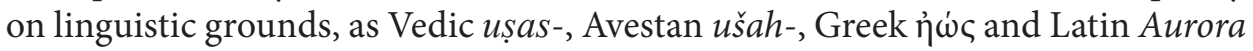
all go back to the Proto-Indo-European verbal root ${ }^{*} h_{2} u s-{ }^{*} h_{2} e u s-$ meaning 'to glow, to flame' extended with an " deities, who we would like to take back to the Proto-Indo-European times, it is not easy to find direct equivalents in other Indo-European traditions. Like in the case of the Zeus, whose name is obviously related to Vedic Dyaus, his function and attributes often correspond to Indra. Likewise, the Dawn goddess -'H $\omega$ c is well-attested in the Homeric epics, but there is no explicit mention of the 'Daughter of the Sun' or the 'Sun-princess' as she is sometimes called in the literature. However, Helen shows some similarities with both Ușās and Sūryấ.

\section{Helen's parenthood, epithets and attributes}

Let us start with the question of her parenthood as well as epithets and attributes which connect her with the divine. The issue of Helen's parenthood occupied the minds of ancient scholars and there have been many competing theories, but almost everybody agrees that her father was Zeus. The Iliad firmly confirms that and states that she had the same mother as the Dioskouroi, that is Leda, although she is not explicitly named in the poem. As to similarities with Sūryấ, only once

${ }^{21}$ P. JACKson, Light from Distant Asterisks. Towards a Description of the Indo-European Religious Heritage, $\mathrm{Nu} 49,2002$, p. 61-102.

${ }^{22}$ M. WEST, Indo-European..., p. 217. 
and in late sources Helen is called the daughter of ${ }^{\prime \prime} \mathrm{H} \lambda_{\mathrm{s}} \varsigma$ - the Sun, which because of its late character is not very significant, but it is an interesting remark, highlighting Helen's solar connotations ${ }^{23}$. The main controversy revolves around the identity of Helen's mother. Hesiod's Catalogue of Women suggests Leda ${ }^{24}$. However, the Cypria states that Helen was the daughter of Zeus and Nemesis who laid an egg with Helen with it, and Leda was her adoptive mother ${ }^{25}$. The best-known version is that it was Leda who laid the egg from which Helen was born. In truth, we cannot tell if the oldest authors knew the story of the birth from an egg.

The whole matter is important from the comparative point of view, because, strikingly, it does find a parallel in the Baltic region. The Lithuanian mythology knows the figure of Sáulès dukrýtè, the Latvian - Saules meita - Daughter of the Sun. They have spread to Estonia and Finland. In Estonia, she became Salme and was said to be have been born from a goose-egg, just like Helen ${ }^{26}$.

Another interesting area are Helen's epithets and attributes which connect her both with the divine and with the Indo-European tradition. An excellent review of this topic has been prepared by L. Clader in her monograph on Helen, where she shows that Helen shares her epithets mostly with goddesses rather than mortal women, for example $\lambda \varepsilon v \kappa \omega \dot{\lambda} \varepsilon v 0 \varsigma$ - white-armed - used predominantly of Hera,

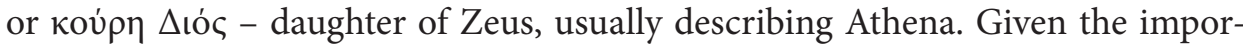
tance of the formulaic nature of these phrases and their archaic character, it might suggest that earlier in the epic tradition Helen did belong more to the realm

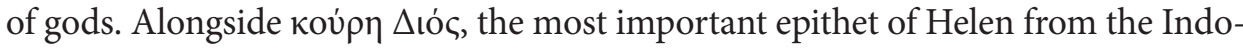
European perspective is $\Delta$ iò $\theta v \gamma \dot{\alpha} \tau \eta \rho$ with the same meaning, also often used to describe Aphrodite, which etymologically and semantically corresponds exactly to Vedic epithet of Ușās - Dawn - duhitā Diváh or Divó duhitā́ - daughter of Dyaus (Heaven) ${ }^{27}$. This is crucial, because Ușās is not only the daughter of Dyaus, but is sometimes called the sister of the Aśvins, born on the yoke of their chariot ${ }^{28}$.

${ }^{23}$ Ptolemy Hephaestion ap. Photius, Biblioteca, 149a31, [in:] Ptolemaei Hephaestionis Novarum historiarum ad variam eruditionem pertinentium excerpta e Photio, ed. J.I.G. Roulez, Lipsiae 1834, p. 90: Singulare sane videretur, quod infra Ptolemaeus Helenam perhibet Solis et Ledae filiam.

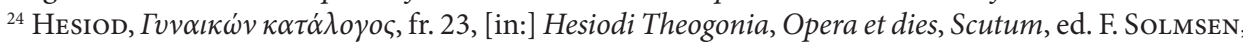
R. Merkelbach, M. West, ${ }^{2}$ Oxford 1983 (cetera: Hesiod), p. 120.

${ }^{25}$ Cypria, fr. 9, [in:] Poetarum epicorum Graecorum. Testimonia et fragmenta, ed. A. BERnABÉ, Leipzig 1987 [= BSGR], p. 49.

${ }^{26}$ W. Mannhardt, Die lettischen Sonnemythen, ZE 7, 1875, p. 314sqq; M. West, Indo-European..., p. $228-231$.

${ }^{27}$ Analysis of Helen's epithets see L. Clader, Helen..., p. 47sqq. On the epithet of Daughter of the Sky see M. West, Indo-European..., p. 219 and Die Hymnen des Rig Veda, 10.39.12, ed. T. Aufrecht, ${ }^{2}$ Bonn 1877, digitized by B.A. Van Nooten, G.B. Holland, http://gretil.sub.uni-goettingen.de/ gretil/1_sanskr/1_veda/1_sam/1_rv/rvh1-10u.htm [27 IX 2018] (cetera: RV).

${ }^{28} \mathrm{RV}$ 1.180.2: when your sister [=Dawn] will bring you, o you welcomed by all, and (the singer) solemnly invokes you for victory's prize and for refreshment, o honey-drinkers, translation: S.W. JAMISON, J.P. Brereton, The Rigveda. The Earliest Religious Poetry of India, vol. I, Oxford 2014 [= SAR] (ce- 
It is difficult to decide how to treat such passages, because the Aśvins were sons of Saranyū and Sūrya in his form of Vivasvan, or sometimes Savitr, another solar deity, while Ușās is clearly the daughter of Dyaus, thus it is more reasonable to treat this is a metaphor for companionship, rather than an indication of real kinship.

\section{Relationship with the Divine Twins}

The most obvious place to go when we want to establish Helen's Indo-European provenience is her relationship with her twin brothers - the Dioskouroi - the Greek version of the Divine Twins, known in the Vedas as the Aśvins. The Proto-Indo-European origins of the myth of the Divine Twins is a topic for another paper, but it is relatively uncontroversial and widely accepted by linguists and historians of religion. What is most important for us is the similarity of the relationship between the Aśvins and the Vedic goddesses Uūs and Sūryấ, and between the Dioskouroi and Helen. Thus, even though 'H $\omega \varsigma$ s is still present in Homeric mythology as a separate divinity, the attributes of the Proto-Indo-European goddess of Dawn are divided between several figures, including'H $\omega \varsigma$, , Aphrodite and Helen $^{29}$. One has to note the especially close link between Aphrodite and Helen in Greek mythology and the story of the Trojan War. In the Vedic mythology, the Aśvins represent the light of sunrise and sunset, they accompany Ușās in a golden chariot. They both married together Súryā - the daughter of the Sun. Their associations with the Sun and the Dawn are very obvious, but their exact relationship is not. The way we interpret this relationship between the Aśvins, Ușās and Súryā, determines how we want to translate it into the Greek model. This is the most problematic matter. Since Aśvins are both strongly associated with Ușās and Sūryấ - the former being called their sister and the later their wife, scholars are at pains recreating this pattern in the Greek mythology.

While Aśvins and Dioskouroi are quite obviously equivalent, it is difficult to decide whether it is better to link Helen with Ușās or with Sūryă. On one hand, the argument for Ușās is the exact same epithet of $\Delta$ iò $\theta v \gamma \alpha \dot{\tau}\rceil \eta \rho$ and passages declaring Ușās the sister of Aśvins, just like Helen is the sister of Kastor and Polydeukes. On the other hand, if we disregard them and assume that Ușās and Aśvins were not actually related, the evidence becomes less convincing. If we take Helen as the recreation of Sūryầ - the daughter of the Sun, she is still strongly associated with the Divine Twins, and her double marriage is represented by Helen's bizarre relationship with the Atreidai - Agamemnon and Menelaus. Although she was only married to Menelaus, it was Agamemnon who wooed on his behalf and the two

tera: The Rigveda), p. 382; RV 10.39.12: Drive here with your chariot swifter than thought, which is Rbhus made for you, o Aśvins, and at whose hitching up the Daughter of Heaven [=Dawn] is born and both bright-lit day halves of Vivasvant, translation: The Rigveda, vol. III, p. 1441.

${ }^{29}$ For the relationship between Aphrodite and Eos see D.D. Boedeker, Aphrodite's Entry into Greek Epic, Leiden 1974, p. 10-17. 
brothers went together on an expedition to win her back ${ }^{30}$. The Dioskouroi are somewhat related to Helen's marriage as well, because according to Hesiod, they organised the contest for her hand and chose the victor.

The etymology of Helen's name and her relationship with the Divine Twins do not point to any clear solution, because both Ușās and Sūryấ have clearly a strong connection with the Aśvins. Ultimately, any attempts to decisively equate Helen with either Ușās or with Sūryấ are going to be inconclusive. There are two possibilities: the first one is that Helen simply started to take over the attributes and imagery of' $H \omega \omega c$, the second one is that she is the Greek embodiment of the Indo-European daughter of the Sun. However, these two options are not mutually exclusive, especially that both the Dawn and the Daughter of the Sun are thematically very similar to each other. If we believe that Helen's name is indeed very archaic and means 'Lady of Light', then it would fit more that she is the Greek reflection of the Sun-princess, who was thematically so close to Dawn, that with time she started to take over her epithets.

\section{Story of abduction and rescue}

Apart from all the solar connotations, Helen represents a well-known Indo-European theme of a kidnapped wife. It has come to the attention of many scholars that both in the two Indic epics: the Mahäbhärata and the Rāmayyana and in the Iliad, the main plot revolves around an abduction of a woman. In her excellent article Draupadi on the Walls of Troy, Stephanie Jamison identifies essential, common elements between the two traditions, quite probably inherited from the Indo-European poetic past, shedding some light on the Indo-European practices regarding marriage.

In ancient India, marriage by abduction, called Rākșasa, was a legitimate procedure for the Kșatriya - the warrior class, but only if performed in the correct way, as a ritual. It is even described by Bhīsma, one of the great heroes of the Mahābhärata, as the best way of marrying for a warrior. If done correctly, the family of the bride has to accept it, but if done incorrectly, the family or the former husband can launch an expedition to re-abduct the bride. The crucial element is an act of heroism in abducting a wife, for example defeating the current husband in a duel. Thus, the Iliad and the Ramanyana are the stories of repercussions of an illegitimate abduction ${ }^{31}$.

The scene from book III of the Iliad, when Helen, standing on the walls of Troy, identifies the Greek heroes to Priam, the Trojan king, is directly comparable to

\footnotetext{
${ }^{30}$ Hesiod, fr. 204. 84; E. Cingano, A Catalogue Within a Catalogue: Helen's Suitors in the Hesiodic Catalogue of Women (frr. 196-204), [in:] The Hesiodic "Catalogue of Women". Constructions and Reconstructions, ed. R. Hunter, Cambridge-New York 2005, p. 138.

${ }^{31}$ S. JAmison, Draupadi on the Walls of Troy: 'Iliad' 3 from an Indic Perspective, CA 13, 1994, p. 7-10.
} 
the scene from book III of the Mahābhārata, where Draupadí, the wife of the Pānugavas, is being abducted by king Jayadratha and while they are escaping in his chariot, she is asked to identify her five husbands pursuing them. It is important to note that that the identification is the legal requirement - dharma - in these circumstances $^{32}$. The Pandiavas defeat the army of king Jayadratha and spare his life - a sign of humiliation rather than pity.

The corresponding episode in the Iliad follows the same scenario of the counter-abduction. The identification takes place at the first encounter between the Greeks and the Trojans in the Iliad, the fact that it is the tenth year of the war seems to be insignificant, in fact many literary scholars claim that the episode originally came from another epic story, because it clearly does not make sense at this point in the war ${ }^{33}$. S. Jamison suggests that the words of Helen, who is the focal point of the whole scene, are crucial in this episode as they legimitise the duel and the violence that is about to happen. Like in the case of Draupadí, it was dharma - the law, which explains its presence in the poem, when in fact Priam must have been able to identify all the major Greek heroes after ten years of fighting ${ }^{34}$. Even the syntax of the passages is similar. Draupadí describes each of her husbands with two or three lines of relative clauses, revealing their name at the end. The Iliad presents it as a dialogue between Priam and Helen, where Priam asks about the heroes describing them also with relative clauses and Helen replies with the name. The oath taken by Menelaus and Paris before their duel also reflects some inherited elements. Calling Zeus and Helios for witness brings up the important distinction between the legitimate abduction with witnesses and an illegitimate one without any $y^{35}$. The duel is a pivotal element as a heroic deed - it will either legitimise Paris' abduction or Menelaus' re-abduction. The ending of the scene in the Iliad is seemingly very different - Aphrodite covers defeated Paris in the mist and takes him back to Helen. However, it is similar to Mahäbhärata in the way that Paris, having violated the warrior's code does not deserve a noble death on the battlefield. Moreover, as this episode seems to be taken from an earlier period of the war, it cannot provide a conclusion to the story for narrative reasons, since we would not get the rest of the epos.

Another parallel with the Indic epics goes back to 'Helen of the tree' and her side as a vegetation deity. Another kidnapped wife - Sitā - originally was also a vegetation deity and her name literally means 'furrow's6.

\footnotetext{
${ }^{32}$ Ibidem, p. 10-11.

${ }^{33}$ Ibidem, p. 1sqq. and notes.

${ }^{34}$ Ibidem, p. 13.

${ }^{35}$ Ibidem, p. 15.

${ }^{36}$ RV 4.57.6-7: Become inclined our way, well-portioned Furrow [skr. site]. We will extol you, so that you will be well-portioned for us, so that you will be well-fruited for us. Let Indra lay down the Furrow [skr. sìtām]; let Pūṣan extend her straight, translation: The Rigveda, vol. I, p. 643.
} 
Lowell Edmunds adds Celtic, specifically Welsh, stories fitting the abduction paradigm $^{37}$. It is also worth mentioning that Paris was not Helen's first kidnapper. As a child, she had been abducted by Theseus, who desired to marry a daughter of Zeus. That time, her brothers Castor and Polydeukes managed to rescue her.

The fact that Helen is repeatedly the main character of stories about abduction of women, which have direct parallels in other Indo-European traditions, most explicitly Indic, as we have just seen, reinforces her position as a deeply IndoEuropean figure in the Greek mythology. This is a completely new and separate angle from the question of her role of the prototypical 'Daughter of the Sun' or sharing attributes with the Dawn goddess. The two deeply Indo-European themes coincide within her character in the most archaic Greek literature.

\section{Story of eidolon}

As I mentioned before, O. Skutsch prefers to align the Helen with Vedic Saranyū, mainly on shaky etymological grounds. Saranyū is of course also closely connected with the Aśvins being their mother, and with the Sun, being the wife of Sứrya. It has to be mentioned that a striking similarity between Helen and Saranyū is the theme of an eidolon, as it is usually called. Saranyu decided to leave her husband, but she left an image of herself, so that he would not realise that she was gone. This immediately reminds us of the story of Stesichorus, who composed a poem absolving Helen from the blame for the Trojan War, saying that she in fact did not go to Troy, it was only her eidolon - her image, while she herself spent that whole time in Egypt. There is, however, no evidence whether this story comes from some older tradition, or is entirely a product of poet's imagination and does not point to any common ancestry of Helen and Saranyū. In light of much stronger arguments for linking Helen with Sūryấ - the daughter of the Sun, both linguistically and culturally, it remains but an interesting detail ${ }^{38}$.

$$
* * *
$$

Helen is a figure deeply rooted in the Indo-European culture. Her name is clearly of Indo-European origins, although there is still controversy regarding its exact etymology. Her strong connection with the Divine Twins and her solar affinities make a strong case for regarding her as a Greek product of the Proto-IndoEuropean Daughter of the Sun, also incorporating some attributes of the Dawn goddess. Her local cults in parts of Greece, most notably Laconia, suggest that she was considered to be a goddess, not just a mortal heroine.

${ }^{37}$ L. Edmunds, Stealing Helen. The Myth of the Abducted Wife in Comparative Perspective, Princeton 2016, p. 93-95.

${ }^{38}$ More on the story of Helen's eidolon vide N. Austin, Helen of Troy and Her Shameless Phantom, Ithaca-London 1994 [= MPo]. 
Apart from that, Helen is the main character of the Indo-European story of wife abduction, finding close narrative parallels in the Mahäbhärata and the Ràmāyana. The comparative analysis of S. Jamison not only provides a better interpretation of the scene in Iliad III, but additionally connects Helen with the Indo-European world.

\section{Bibliography}

\section{Primary Sources}

Aeschylus, Agamemnon, [in:] Aeschylus, vol. II, Agamemnon. Libation-Bearers. Eumenides. Fragments, ed. et trans. H.W. SмYтн, London 1926 [= Loeb Classical Library, 146], p. 2-207.

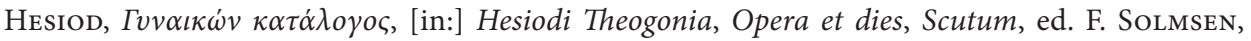
R. Merkelbach, M. West, ${ }^{2}$ Oxford 1983, p. 113-190.

Die Hymnen des Rig Veda, ed. T. Aufrecht, ${ }^{2}$ Bonn 1877, digitized by B.A. Van Nooten, G.B. Holland, http://gretil.sub.uni-goettingen.de/gretil/1_sanskr/1_veda/1_sam/1_rv/rvh1-10u.htm [27 IX 2018].

Pausanias, Description of Greece, vol. II, Books 3-5 (Laconia, Messenia, Elis 1), trans. W.H.S. Jones, H.A. Ormerod, Cambridge Massachusett-London 1926 [= Loeb Classical Library, 188].

Philostrate, Sur les Héros, ed. et trans. S. Follet, Paris 2017 [Collection des universités de France. Série grecque, 531e].

Poetarum epicorum Graecorum. Testimonia et fragmenta, ed. A. BERnABÉ, Leipzig 1987 [= Bibliotheca scriptorum Graecorum et Romanorum Teubneriana].

Ptolemy Hephaestion ap. Photius, Biblioteca, [in:] Ptolemaei Hephaestionis Novarum historiarum ad variam eruditionem pertinentium excerpta e Photio, ed. J.I.G. Roulez, Lipsiae 1834.

The Rigveda. The Earliest Religious Poetry of India, trans. S.W. JAMIson, J.P. Brereton, vol. I-III, Oxford 2014 [= South Asia Research].

Supplementum Epigraphicum Graecum, vol. XXVI, (1976-1977), ed. H.W. Pleket, R.S. Stroud, Alphen aan den Rijn-Germantown 1979.

\section{Secondary Literature}

Austin N., Helen of Troy and Her Shameless Phantom, Ithaca-London 1994 [= Myth and Poetics].

Boedeker D.D., Aphrodite's Entry into Greek Epic, Leiden 1974.

Chantraine P., Dictionnaire Étymologique de la Langue Grecque, Paris 1968.

Cingano E., A Catalogue Within a Catalogue: Helen's Suitors in the Hesiodic Catalogue of Women (frr. 196-204), [in:] The Hesiodic "Catalogue of Women". Constructions and Reconstructions, ed. R. Hunter, Cambridge-New York 2005, p. 118-152.

Clader L., Helen. The Evolution from Divine to Heroic in Greek Epic Tradition, Leiden 1976 [= Mnemosyne. Bibliotheca Classica Batava. Supplementum, 42].

Edmunds L., Stealing Helen. The Myth of the Abducted Wife in Comparative Perspective, Princeton 2016.

Höfler S., "La Belle Hélène", a Generic Brothel, and the Development of *CRHC Sequences in Ancient Greek, https://www.academia.edu/34917682/La_belle_Helene_Handout_SHORT [13 I 2018].

JACKson P., Light from Distant Asterisks. Towards a Description of the Indo-European Religious Heritage, "Numen" 49, 2002, p. 61-102. 
Jamison S., Draupadí on the Walls of Troy: 'Iliad' 3 from an Indic Perspective, "Classical Antiquity" 13, 1994, p. 5-16.

Lexikon der indogermanischen Verben, ed. H. Rix et al., Wiesbaden 2001.

Mannhardt W., Die lettischen Sonnenmythen, "Zeitschrift für Ethnologie" 7, 1875, p. 281-329.

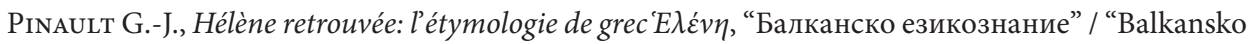
ezikoznanie" 54, 2015, p. 155-172.

Pokorny J., Indogermanisches Etymologisches Wörterbuch, vol. I, Bern-München 1959.

Sinler A.L., New Comparative Grammar of Greek and Latin, New York-Oxford 1995.

Sкuтsch O., Helen, Her Name and Nature, "Journal of Hellenic Studies” 107, 1987, p. 188-193.

Sмоот G., Helenos and the Polyphyletic Etymologies of Helen, https://classical-inquiries.chs.harvard. edu/helenos-and-the-polyphyletic-etymologies-of-helen/ [16 X 2017].

West M., Indo-European Poetry and Myth, Oxford 2007.

WIDE S., Lakonische Kulte, Leipzig 1893.

Abstract. As a part of the series on female deities and demons in the Indo-European culture, the article begins by establishing Helen's divine character in the Greek tradition and religion. The first area where the Indo-European character of Helen is displayed concerns the etymology of her name, which has been the subject of discussion and controversy throughout several decades. The most prominent theories are presented, including the concept of Pokorny and West to explain her name as 'Lady of Light' from the Proto-Indo-European root *swel- or *swelh the idea of Skutsch to connect Helen with Vedic Saranyū, the etymology by Clader relying on the local Greek ritual practices and finally the new etymology provided by Pinault explaining the name as 'having a year like a thread' from Proto-Indo-European "suh1-l-hleno. The second part of the article deals with the cultural, literary and religious attributes of Helen which connect her with the Indo-European world, especially with the Vedic tradition. The most interesting aspects include the issue of Helen's parenthood and her birth, her relationship with her brothers - the Dioskouroi - the prototypical Indo-European Divine Twins, as well as similarities with Vedic goddesses Ușās - Dawn and Sūryấ - the Sun Princess. The final part of the article establishes Helen as the Greek representation of the Indo-European myth of an abducted wife. Relying heavily on the analysis of Jamison, it draws on the similarities between the passages in the book III of the Mahäbhärata and the book III of the Iliad, which from the comparative perspective explains well the inclusion of this scene in the Homeric epic and Helen's role in it as well as sheds more light on the Indo-European practices regarding marriage. Lastly, the article mentions a connection between Helen and Vedic Saranyū by the story of eidolon - a phantom, which both characters created at certains points in some literary traditions.

Keywords: Helen, Greek mythology, comparative mythology, Indo-European religion, Greek etymology, Greek religion

Maciej Jaszczyński

École Pratique des Hautes Études

Les Patios Saint-Jacques 4-14 rue Ferrus

75014 Paris

maciej.jaszczynski@etu.ephe.psl.eu 